\section{The Gulf crisis and research}

SIR-The world community has been almost unanimous in condemning the Iraqi invasion and occupation of Kuwait and in demanding the immediate withdrawal of Iraqi forces from Kuwait and the restoration of the constitutional government of Kuwait. It is indeed heartening to see the world react swiftly and forcefully to check this unprovoked aggression. The damage and suffering brought about by this aggression are huge, both materially and psychologically. Kuwait, a small, peaceful and thriving state, albeit with its own share of problems caused by accelerated growth, has been turned into a shambles. The lives of the Kuwaitis and other nationals residing in Kuwait have been abruptly disrupted, and more than half the population have fled in fear. We have all seen on the television screen the plight of the Asian workers who fled Kuwait, only to be trapped in the makeshift refugee camps on the borders of Iraq and Jordan. The few video pictures and the eye-witness reports from those lucky ones who were able to escape the forced guest status in Kuwait tell of a sad wholesale destruction of beautiful and peaceful Kuwait.

Lost in the news are the stories being told of the mad and irrational dismantling and destruction of scientific and research institutions in Kuwait. In particular, eyewitness reports tell of systematic and organized theft from the Kuwait Institute for Scientific Research, KISR. Computers, scientific instruments, books, supplies and even the rugs have been carted off. One of the leading scientific research institutions of the Arab world is now in disarray. Important research experiments in biology, ecology and the environment have been interrupted and, in some cases, years of field and laboratory work will have to be repeated. KISR was a truly international research institution; it employed more than 1,000 scientists, engineers and support staff from about 40 different nationalities, including those from the United States and Canada, Western and Eastern Europe, Asia, Africa and the Arab world.

KISR research programmes cover a wide range of mission-orientated research areas related to Kuwait, the Arab world and the developing countries. Among the major research activities pursued at KISR are: sea-water desalination and natural water resources, solar and other forms of renewable energy, fisheries and oceanography, biotechnology, arid land agriculture, air pollution and other desert and marine environmental problems of the Gulf region, petroleum and petrochemical technology, urban engineering, computer and microprocessor applications, applied economic and operation research and other practical research.

KISR's new facilities, completed in 1986, include some of the most modern multipurpose applied scientific laboratories in the world, a major scientific information centre with over 100,000 scientific books and periodicals supported by automated information systems connected to data centres elsewhere. The KISR computer centre features many mainframes, including a newly acquired IBM 3090 and hundreds of PCs and workstations. KISR is empty now. We are told that the buildings are being used as military headquarters. Other scientific and educational institutions in Kuwait such as Kuwait University have fared no better.

All present and previous colleagues at KISR and other scientists who visited KISR will be deeply saddened at what has happened to KISR, and will join in calling upon our colleagues throughout the world to voice their opposition to such shocking actions, and hope that the world scientific community will call upon the Iraqi authorities to refrain from such destructive action and to restore KISR properties and facilities. We are confident that, as soon as Kuwait regains its independence and sovereignty, the world scientific community will help KISR to become once again a centre for creative applied research for the benefit of all mankind, the vision and the dream that guided all those who helped build KISR and make it a reality.

ADNAN A. SHIHAB-ELDIN (Principal Research Scientist and former Director General, KISR)

Lawrence Berkeley Laboratory,

1 Cyclotron Road,

Berkeley, California 94720, USA

Department of Physics,

RICHARD WILSON

Harvard University,

Cambridge, Massachusetts 02138, USA

SIR-I must take issue with your leading article "Beyond the trouble in the Gulf" (Nature 346, 683; 1990). You suggest that Iraq was the only Middle East oilproducing country that has spent oil revenues on a national programme ". . . being militarily strong in this case".

The leaders of the United Arab Emirates (UAE) have invested heavily in national programmes, including health, education, conservation, the greening-ofthe-desert and agriculture. The leading article also suggested that ". . . the oil producers of the Middle East ... seem not to have turned their minds to creating a first-rate university somewhere". This statement does a disservice to the longstanding efforts of the leaders of the Emirates, particularly H. H. Sheikh Zayed Bin Sultan Al Nahyan, president of the UAE and H. H. Sheikh Nahyan Bin Mubarak Al Nahyan, chancellor of the United Arab Emirates University.

They and the dedicated faculty, drawn from other Arab countries as well as from Western countries, are working very hard to create an outstanding, modern university at Al Ain, Abu Dhabi. Those of us working with the United Arab Emirates University are impressed with the commitment of funds and the insistence on excellence that characterize their effort. In conjunction with the UAE University, H. H. Sheikh Zayed Bin Sultan Al Nahyan has established a new Desert and Marine Environment Research Center, dedicated to conservation and exploitation of the natural resources of the UAE. The Emirates have also invested in a strong system of technical colleges covering civil engineering, electronics, business and computer skills.

SIDNEY B. SIMPSON JR

University of Illinois,

Department of Biological

Sciences (M/C 066),

Box 4348, Chicago, Illinois 606030, USA

\section{Doctor who?}

SIR-Many of us must wonder what proportion of the references that adorn scientific papers have actually been look up, let alone read and inwardly digested. An example has recently come to my attention of the creation of an entirely new scientific personality as a result of casual citation. A number of articles concerned with fibroblast growth factor have referred in the past few years to the first observation of mitogenic activity in brain extract as having been made by Trowell, Chir and Willmer in $1939^{1}$. It is probable that the middle author made only a limited contribution to this work as he is actually the surgical qualification held by the first author. In those days, Journal of Experimental Biology listed the degrees of the authors, and so their names on the title page read "O. A. Trowell, M.B., B.Chir. and E. N. Willmer, M.A." The neogenesis of Dr Chir is thus easily explained.

Students of the history of embryology might be interested to know that it was also in 1939 that the first description was published of a mesoderm-inducing activity from adult tissues ${ }^{2}$. Had the two groups got together, they might have anticipated by nearly 50 years the modern flurry of activity on the role of growth factors as agents of embryonic induction.

J. M. N. SLACK

Imperial Cancer Research Fund

Laboratories,

Department of Zoology,

South Parks Road, Oxford OX1 3PS, UK

\footnotetext{
1. Trowell, O. A. \& Willmer, E. N. J. exp. Biol. 16, 60-70 (1939)

Chuang, H. H. Wilhelm Roux' Arch. EntwMech. Orgs. 139 $556-638$ (1939)
} 